\title{
Pengembangan Aplikasi Penerimaan Mahasiswa Baru Berbasis Android dengan Push Notification di STMIK Atma Luhur
}

\author{
Lukas Tommy $^{\left[1^{*}\right.}$, Delpiah Wahyuningsih ${ }^{[2]}$, Parlia Romadiana ${ }^{[3]}$ \\ Program Studi Teknik Informatika ${ }^{[1]}$, [2], Program Studi Manajemen Informatika ${ }^{[3]}$ \\ STMIK Atma Luhur \\ Pangkalpinang, Indonesia \\ lukastommy@atmaluhur.ac.id ${ }^{[1]}$, delphibabel@atmaluhur.ac.id ${ }^{[2]}$, parliaromadiana@atmaluhur.ac.id ${ }^{[3]}$
}

\begin{abstract}
STMIK Atma Luhur Pangkalpinang hold new student admission activity every year where the matriculant at present can register by come directly to the information section, fill in Google Forms form, or contacting PMB committee's WhatsApp. These three methods have several disadvantages such as additional expenses for stationery and transportation, and limited registration time. Furthermore, the committee must reenter data from matriculant with the existing desktop system because the database had not been integrated and matriculant need to be contacted one by one if there are changes such as changes in briefing schedule This resulted in STMIK Atma Luhur new student admission activity become less efficient, tiring and slow. The proposed solution is to create an Android-based new student admission application with push notification and integrated with the current Oracle database. Push notification allows notifications to be sent directly to certain parties if an event occurs such as new registration or registration is responded by admin. This means new registrations can be immediately known and responded by admin. Integrated database allow data inputted through application can be saved immediately to Oracle database. The results of Likert Scale measurement for the questionnaire distributed to $\mathbf{4 7 5}$ respondents showed a fairly good level of user satisfaction towards the application, which was an average of 3.39. A score of 3.33 was obtained for statement regarding application make registration at STMIK Atma Luhur easy and efficient. A statement regarding application make easy and speed up the work of new student admission committee get a score of 3.48 . Furthermore, statement regarding information related to new student admission in application are interesting, easily accessible, and clear get a score of 3.25 .
\end{abstract}

Keywords- Android, Mobile Application, New Student Admission, Push Notification, Registration

Abstrak- STMIK Atma Luhur Pangkalpinang setiap tahunnya mengadakan kegiatan PMB dimana saat ini camabanya dapat mendaftar dengan datang langsung ke bagian informasi, mengisi formulir Google Forms, atau menghubungi WA panitia PMB. Ketiga cara pendaftaran ini memiliki beberapa kekurangan seperti terdapat pengeluaran tambahan untuk ATK dan transportasi, serta waktu pendaftaran yang terbatas. Selain itu, panitia harus menginput ulang data dari camaba dengan sistem desktop yang ada karena belum terintegrasinya database dan camaba perlu dihubungi satu per satu jika ada perubahan seperti perubahan jadwal pengarahan. Hal ini mengakibatkan kegiatan
PMB STMIK Atma Luhur menjadi kurang efisien, melelahkan, dan lambat. Solusi permasalahan yang diusulkan adalah membuat aplikasi PMB berbasis Android dengan push notification serta terintegrasi dengan database Oracle saat ini. Push notification memungkinkan notifikasi langsung dikirimkan ke pihak tertentu jika suatu peristiwa terjadi seperti ada pendaftaran baru atau pendaftaran ditanggapi admin. Hal ini berarti pendaftaran baru dapat langsung diketahui dan ditanggapi oleh admin. Database terintegrasi memungkinkan data yang diinput camaba melalui aplikasi dapat langsung tersimpan ke database Oracle. Hasil pengukuran Skala Likert terhadap kuesioner yang dibagikan kepada 475 responden menunjukkan tingkat kepuasan pengguna yang cukup baik terhadap aplikasi, yaitu rata-rata sebesar 3,39. Skor 3,33 diperoleh untuk pernyataan mengenai aplikasi membuat pendaftaran di STMIK Atma Luhur menjadi mudah dan efisien. Pernyataan mengenai aplikasi memudahkan dan mempercepat pekerjaan panitia PMB memperoleh skor 3,48. Selain itu, pernyataan mengenai informasi terkait PMB pada aplikasi menarik, mudah diakses, dan jelas memperoleh skor 3,25.

Kata Kunci-Android, Aplikasi Mobile, Penerimaan Mahasiswa Baru, Push Notification, Registrasi

\section{PENDAHULUAN}

Untuk mendapatkan mahasiswa baru, Perguruan Tinggi Swasta (PTS) maupun negeri melakukan suatu kegiatan yang dinamakan Penerimaan Mahasiswa Baru (PMB) secara rutin pada suatu periode [1]. STMIK Atma Luhur Pangkalpinang setiap tahunnya mengadakan kegiatan PMB yang dimulai dari awal semester genap sampai dengan sebelum awal semester ganjil. Jadwal dan informasi PMB STMIK Atmaluhur diumumkan pada surat kabar, website kampus, baliho di depan kampus, dan sosial media. Pada saat ini calon mahasiswa baru (camaba) yang ingin mendaftar di STMIK Atma Luhur harus datang langsung ke bagian informasi kampus, ataupun dengan mengisi formulir Google Forms yang terdapat di Uniform Resource Locator (URL) daftar.atmaluhur.ac.id. Selain itu, camaba juga dapat mendaftar dengan menghubungi panitia PMB yang nomor WA / WhatsAppnya tertera di pengumuman PMB.

Proses pendaftaran seperti yang telah disebutkan memiliki 
beberapa kekurangan. Terdapatnya biaya Alat Tulis Kantor (ATK) yang perlu dikeluarkan pihak kampus apabila camaba mendaftar dengan datang langsung ke kampus[2]. Selain itu, camaba perlu membawa berbagai berkas dan mengeluarkan biaya transportasi terutama mereka yang berada di luar kota. Tidak jarang berkas yang dibawa camaba tidak lengkap sehingga mereka harus datang kembali. Camaba juga hanya dapat mendaftar langsung pada hari kerja dan di luar jam istirahat bagian informasi. Formulir yang terdapat pada Google Forms yang ada saat ini belum memiliki fitur upload berkas seperti bukti pembayaran pendaftaran dan foto nilai rapor ratarata terbaru. Untuk mengakses Google Forms tersebut, camaba harus mengetahui alamat URLnya terlebih dahulu [1], yang tidak jarang terdapat kesalahan saat camaba mengetiknya. Pendaftaran melalui WA juga kurang efektif karena panitia PMB harus menanyakan kepada camaba mengenai biodata dan foto yang perlu dikirimkan, selain itu foto dan informasi pendaftaran sulit dikelola dan adanya resiko smartphone yang digunakan panitia rusak atau hilang. Ketiga cara ini dirasakan kurang efisien karena data dari camaba perlu diinput kembali oleh bagian informasi ke sistem informasi berbasis desktop yang sedang berjalan serta Google Forms belum terintegrasi dengan database yang ada. Selain itu, apabila ada pengumuman terkait PMB misalkan perubahan jadwal pengarahan, panitia perlu menyebarkan pengumuman tersebut baik melalui WA, sosial media, website, surat kabar maupun menelpon masingmasing camaba yang bisa saja dilewatkan oleh camaba karena tidak adanya notifikasi. Panitia juga harus secara berkala memeriksa apakah ada camaba baru yang mendaftar dengan menggunakan Google Forms karena tidak adanya fitur notifikasi.

Untuk mengatasi permasalahan-permasalahan yang ada pada kegiatan PMB di STMIK Atma Luhur yang telah dijabarkan, akan dibangun suatu aplikasi PMB berbasis Android. Aplikasi yang akan dibangun memiliki berbagai fitur seperti terintegrasinya data yang diinput camaba di aplikasi dengan database kampus. Terdapat notifikasi real-time yang dikirim ke camaba apabila ada pesan broadcast, pengumuman baru dan pendaftarannya ditanggapi oleh admin PMB menggunakan Firebase Cloud Messaging (FCM). Admin PMB juga akan dikirimkan notifikasi apabila ada camaba yang mendaftar atau mengubah data pendaftarannya. Selain untuk mendaftar, aplikasi ini juga dapat digunakan sebagai media informasi dan promosi kampus layaknya katalog elektronik yang menyediakan informasi seperti profil dan lokasi kampus di peta, biaya pendaftaran, program studi dan fasilitas yang dimiliki kampus. Smartphone Android dipilih sebagai environment dari aplikasi PMB yang akan dibangun karena sifatnya yang mobile dan jumlah penggunanya jauh lebih banyak dibandingkan dengan iPhone, web, dan desktop [3]. Aplikasi Android ini nanti juga dapat diunduh di Google Play Store dan dapat langsung digunakan camaba tanpa harus mengetik alamat URL tertentu. Selain itu, FCM dipilih karena lebih simpel dan biayanya lebih murah dibandingkan SMS (Short Message Services) gateway atau broadcast WhatsApp dalam menotifikasi informasi ke seluruh camaba [1].

Penelitian-penelitian yang relevan dengan penelitian mengenai pembangunan aplikasi PMB yang akan dilaksanakan di antaranya pengembangan aplikasi berbasis website, desktop, ataupun Android yang dapat saja dilengkapi dengan fitur notifikasi. Penelitian mengenai aplikasi registrasi berbasis Android misalnya sistem informasi pendaftaran pasien klinik berbasis Android untuk mendaftar pemeriksaan dan menampilkan pemberitahuan terkait nomor antrian pasien [4]. Ada juga aplikasi Android untuk pendaftaran poliklinik anak, gigi, dan mata yang dapat mempercepat antrian dalam proses pendaftaran dan pembayaran dimana tingkat kepuasan pengguna karyawan dan pasien terhadap aplikasi berturut-turut adalah $81,5 \%$ dan $79,6 \%$ [5].

Penelitian yang membahas pengembangan aplikasi registrasi berbasis website di antaranya sistem informasi registrasi online untuk Penerimaan Siswa Baru (PSB) berbasis web yang memudahkan proses PSB, membuat penyimpanan data menjadi rapi, dan memungkinkan informasi terkait PSB diperoleh dengan mudah, tepat dan akurat [6]. Selain itu aplikasi PSB yang terkomputerisasi, misalkan yang berbasis website dapat mengurangi biaya pencatatan dan rekap data PSB seperti biaya kertas, cetak, dan ATK [7] [8]. Hal ini menyebabkan proses administrasi PSB menjadi lebih efektif dan efisien [9]. Implementasi framework Bootstrap pada aplikasi PMB berbasis web membuat tampilan aplikasi menjadi simpel, ringan, dan responsif sehingga tampilannya sama apabila diakses menggunakan ponsel ataupun komputer [10]. Terdapat pula aplikasi untuk pendaftaran pasien rawat jalan rumah sakit yang dapat langsung diakses tanpa harus memasang aplikasi layaknya pada aplikasi berbasis desktop serta dapat diakses tanpa menggunakan jaringan lokal sehingga lebih praktis dan pemeliharannya mudah [11]. Mubarok dkk [12] membandingkan metodelogi pengembangan perangkat lunak Relational Unified Process (RUP) dan prototype dalam aplikasi PSB berbasis web dimana RUP sangat cocok untuk pengembangan software berorientasi objek dibandingkan prototype. Ada juga sistem informasi berbasis web yang memudahkan calon siswa dan petugas PSB dalam melakukan kegiatan registrasi ulang karena dapat diakses dari luar lingkungan sekolah [13].

Terdapat pula penelitian yang memadukan website dengan Android dalam mengembangkan aplikasi registrasi. Irfan dan Soyusiawaty [14] membuat aplikasi PSB berbasis Android dan web masing-masing untuk calon siswa dan admin PSB dimana informasi kelulusan disampaikan ke wali calon siswa menggunakan SMS gateway sehingga proses PSB bisa selesai dalam waktu satu hari saja.

Beberapa penelitian lainnya mengintegrasikan teknologi SMS gateway ke sistem informasi yang dibuat untuk menyampaikan informasi seperti pengumuman kelulusan kepada pengguna. Sebagai contoh Meta dkk [15] memadukan sistem informasi PMB berbasis web dengan SMS gateway yang mampu menginformasikan kelulusan camaba dalam bentuk SMS. Sama halnya dengan Ivanka dkk yang mengkombinasikan SMS gateway dengan aplikasi web PSB [16].

Ada juga penelitian yang menerapkan teknologi pemberitahuan yang lebih baru daripada SMS Gateway, yaitu menggunakan push notification. Salah satunya aplikasi Android dengan push notification yang menjadi media PMB dan mampu menyampaikan informasi PMB terbaru kepada 
camaba secara real-time [1]. Push notification pada penelitian tersebut menggunakan Google Cloud Messaging (GCM) yang saat penelitian ini dilakukan telah berganti nama menjadi FCM.

Berdasarkan paparan di atas, akan dibangun aplikasi PMB berbasis Android dengan menerapkan push notification menggunakan FCM. Diharapkan dengan adanya aplikasi ini camaba dapat dengan mudah mendaftar di STMIK Atma Luhur dan mendapatkan informasi terkait PMB sekaligus fasilitas kampus yang ada. Selain itu diharapkan juga aplikasi ini dapat memudahkan panitia PMB menyampaikan pengumuman dan meverifikasi pendaftaran oleh camaba yang mendaftar.

\section{LANDASAN TEORI}

\section{A. Aplikasi}

Aplikasi merupakan sebuah subkelas perangkat lunak komputer yang secara langsung menggunakan kapabilitas komputer dengan maksud melaksanakan suatu pekerjaan sesuai kehendak pengguna [17]. Hal ini berbeda dengan perangkat lunak sistem yang memadukan bermaca-macam kapabilitas komputer, namun tidak secara langsung mengimplementasikannya demi menyelesaikan pekerjaan tertentu. Contoh aplikasi misalnya pengolah kata, lembar kerja, dan pemutar media.

Berbagai aplikasi yang dikombinasikan menjadi satu paket disebut paket aplikasi misalkan Microsoft Office yang menggabungkan aplikasi pengolah kata, lembar kerja, presentasi, dan berbagai aplikasi lain. Aplikasi seperti ini umumnya mempunyai kemiripan antarmuka pengguna. Biasanya aplikasi paket mempunyai kapabilitas agar dapat saling terhubung sehingga menguntungkan pengguna. Sebagai contoh lembar kerja bisa ditanamkan pada berkas pengolah kata meskipun dibuat di aplikasi lembar kerja tersendiri.

\section{B. Pendaftaran}

Pendaftaran atau registrasi merupakan kegiatan pencatatan suatu hal, baik invididu, kelompok, ataupun benda ke dalam register. Register ini sendiri berarti buku catatan atau daftar (bisa nama atau sebagainya) yang tersusun secara bersistem dan menurut abjad [18].

Inti dari kegiatan PMB adalah untuk memudahkan dan melancarkan proses pendaftaran camaba, pendataan, dan pembagian kelompok perkuliahan. Hal ini dilakukan agar proses perkuliahan untuk para camaba ini menjadi lebih terorganisir dan tepat sesuai persyaratan dan aturan kampus. Adapun PMB merupakan kegiatan yang rutin dilaksanakan oleh pihak kampus pada setiap tahun ajaran baru.

\section{Mahasiswa}

Mahasiswa dapat didefinisikan sebagai seseorang yang sedang menjalani pendidikan tinggi di sebuah perguruan tinggi negeri ataupun swasta, yang terdiri atas universitas, sekolah tinggi, ataupun akademi [19].

Transisi dari Sekolah Menengah Atas (SMA) menuju perguruan tinggi meliputi tindakan ke arah satu struktur sekolah yang lebih besar dan tidak bersifat individu, layaknya hubungan terhadap kelompok seusia yang berasal dari kawasan yang lebih bervariasi dan menjadi lebih tingginya perhatian terhadap capaian dan penilaiannya. Mahasiswa sebagai masyarakat kampus memiliki kewajiban pokok seperti belajar, yaitu mengerjakan tugas, membaca literatur, menulis naskah, presentasi, perundingan, menghadiri seminar, dan kegiatankegiatan kampus lainnya. Selain itu, setiap mahasiswa juga berkewajiban untuk menjaga nama baik perguruan tinggi tempat mereka menjalani pendidikan.

\section{Android}

Android merupakan Sistem Operasi (SO) berlandaskan Linux yang didesain untuk perangkat mobile dengan layar sentuh, misalkan telepon pintar dan komputer tablet [20]. Antarmuka pengguna Android biasanya berwujud gerakan langsung, memakai aksi menyentuh layaknya aksi nyata, seperti menggeser, mengetuk, dan mencubit untuk mengendalikan objek di layar, serta keyboard virtual untuk menulis teks.

Selain perangkat layar sentuh, dikembangkan juga Android TV, Android Auto, dan Android Wear dengan antarmuka pengguna yang berbeda-beda. Variasi Android lainnya juga dimanfaatkan pada laptop, konsol permainan, kamera digital, dan perangkat elektronik lainnya. Faktor kepopuleran Android salah satunya disebabkan oleh pembaruan yang terus-menerus dari Google, dan kebebasan bagi pengembang untuk membuat aplikasi Android kemudian menyebarkan atau menjualnya di Google Play Store untuk mengatasi permasalahan yang dimiliki oleh pengguna.

\section{E. Push Notification}

Push notification adalah pesan yang "didorong" dari server backend atau aplikasi ke antarmuka pengguna aplikasi sasaran, misalnya (namun tidak terbatas pada) aplikasi seluler dan aplikasi desktop. Push notification dapat menargetkan perangkat tertentu ataupun sekelompok pengguna, dimana dapat bervariasi dari pesan notifikasi sederhana hingga panggilan yang tak dapat dilihat pengguna ke backend aplikasi pada platform sasaran [21].

Pada tahun 2009, push notification mula-mula dikenalkan oleh Apple, kemudian pada 2010 Google merilis layanannya sendiri yang bernama Google Cloud to Device Messaging yang selanjutnya digantikan oleh Google Cloud Messaging dan kemudian Firebase Cloud Messaging.

Push notification sebagian besar dibagi menjadi 2 pendekatan, notifikasi lokal dan notifikasi remote / jarak jauh. Untuk notifikasi lokal, aplikasi menjadwalkan notifikasi dengan SO perangkat lokal atau sebagai alternatif mengatur sebagai timer dalam aplikasi itu sendiri jika ia dapat terus berjalan di latar belakang. Ketika waktu yang dijadwalkan event tercapai, atau kondisi terprogram event terpenuhi, pesan ditampilkan di antarmuka pengguna aplikasi.

Notifikasi jarak jauh ditangani oleh server jarak jauh. Di bawah skenario ini, aplikasi klien harus terdaftar di server dengan kunci unik. Server kemudian melepaskan pesan terhadap kunci unik untuk mengirimkan pesan ke aplikasi klien melalui protokol klien / server yang disepakati dan klien menampilkan pesan yang diterima. Saat push notification tiba, ia dapat mentransmisikan pesan pendek dan pemberitahuan, menetapkan badge pada ikon aplikasi atau memutar suara 
peringatan untuk menarik perhatian pengguna. Push notification biasanya digunakan oleh aplikasi untuk membawa informasi ke perhatian pengguna. Isi pesan dapat diklasifikasikan dalam kategori pesan obrolan, penawaran khusus vendor, pengingat event, dan perubahan topik berlangganan.

\section{METODOLOGI PENELITIAN}

\section{A. Model Pengembangan Sistem}

Model pengembangan sistem yang digunakan pada penelitian ini adalah model prototype yang merupakan salah satu metode siklus hidup sistem dengan berdasarkan pada model gagasan bergerak untuk membangun model menjadi wujud sistem akhir. Gambar 1 merupakan langkah-langkah pada model prototype.

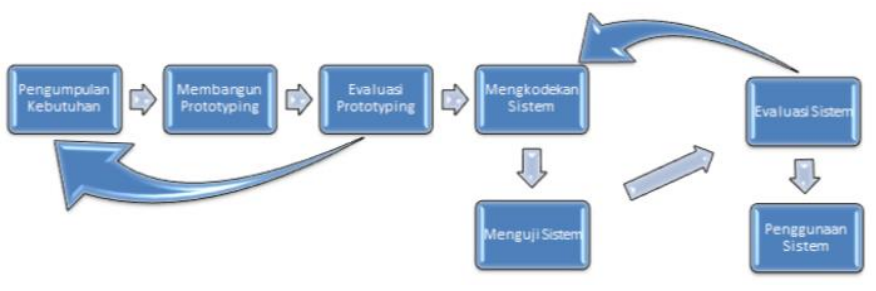

Gambar 1. Tahap-tahap model prototype[22]

Langkah-langkah yang akan dilakukan pada penelian ini berdasarkan Gambar 1 adalah sebagai berikut :

1) Pengumpulan Kebutuhan: Studi literatur, observasi dan wawancara merupakan teknik pengumpulan data yang digunakan pada penelitian ini. Observasi dilakukan pada proses PMB dimulai dari camaba datang ke kampus sampai dengan mendapatkan kartu pengarahan, kemudian form pendaftaran STMIK Atma Luhur yang diisi camaba dipelajari. Selain itu, wawancara dilakukan terhadap panitia PMB dan mahasiswa semester 1 STMIK Atma Luhur. Berdasarkan pengumpulan kebutuhan ini dapat diidentifikasi beberapa masalah yaitu belum adanya sistem online yang dapat digunakan oleh camaba untuk mendaftar sekaligus mengunggah berkas pendaftaran yang diperlukan dimana datanya terintegrasi dengan database kampus pada STMIK Atma Luhur. Selain itu sistem online yang ada saat ini belum dapat mengirimkan notifikasi secara otomatis kepada panitia PMB apabila ada camaba yang baru mendaftar, sehingga perlu diperiksa secara berkala.

Solusi yang dianggap efektif untuk memecahkan permasalahan ini adalah dengan mengembangkan aplikasi PMB berbasis Android yang dilengkapi push notification. Aplikasi ini nantinya dapat mengirimkan notifikasi kepada panitia PMB apabila ada camaba yang mendaftar ataupun mengganti biodatanya. Selain itu aplikasi ini mampu mengirimkan notifikasi kepada camaba saat pendaftarannya ditanggapi panitia PMB. Data yang diinput camaba melalui aplikasi ini juga terintegrasi dengan database kampus, sehingga panitia PMB tidak perlu menginput kembali data camaba ke dalam database kampus menggunakan sistem informasi desktop PMB yang sudah ada.

2) Membangun Prototyping: Perancangan fitur-fitur apa saja yang ada di aplikasi PMB sekaligus tampilan halaman- halaman yang ada dilakukan pada langkah ini.

3) Evaluasi Prototyping: Purwarupa (prototipe) yang dihasilkan pada langkah membangun prototyping setelah itu dievaluasi pihak yang berkepentingan, antara lain panitia PMB dan beberapa siswa kelas 3 SMA atau sederajat. Parameter yang dievaluasi diantaranya menarik tidaknya tampilan halaman aplikasi serta fitur-fitur dari aplikasi PMB. Langkah pengumpulan kebutuhan akan dilaksanakan kembali dengan berdasarkan umpan balik dari pemangku kepentingan seandainya purwarupa ditolak.

4) Mengkodekan Sistem: Desain tampilan halaman dan fitur-fitur yang ada diimplementasikan pada langkah ini agar tercipta suatu aplikasi dimana semua fiturnya berfungsi sebagaimana mestinya. Android Studio adalah Integrated Development Environment (IDE) berbahasa pemrograman Java yang dipakai untuk mendesain tampilan halaman aplikasi serta koding.

5) Menguji Sistem: peneliti secara mandiri menggunakan model pengujian blackbox testing dalam menguji fitur-fitur baik masukan ataupun keluaran yang terdapat pada aplikasi yang dibuat.

6) Mengevaluasi Sistem: Setelah langkah menguji sistem dilaksanakan, langkah selanjutnya adalah mengevaluasi sistem dimana pada langkah ini aplikasi akan diuji kembali oleh pemangku kepentingan. Hal ini dilakukan untuk memastikan apakah aplikasi sudah memenuhi semua kebutuhan dari para pemangku kepentingan sebelum dipublikasikan dan digunakan. Apabila dirasakan belum memenuhi, langkah ini menghasilkan umpan balik yang digunakan sebagai masukan bagi peneliti untuk melaksanakan langkah mengkodekan sistem kembali sehingga dapat mengatasi kekurangan yang ada.

7) Penggunaan Sistem: Hosting aplikasi dilakukan pada server STMIK Atma Luhur dengan domain https://pmb.atmaluhur.ac.id/pmb/ setelah aplikasi selesai dievaluasi oleh pemangku kepentingan. Setelah itu Android Package File (APK) aplikasi diunggah ke Google Play Store sehingga dapat diunduh pihak yang membutuhkan seperti panitia PMB, camaba, ataupun wali camaba STMIK Atma Luhur. APK ini dapat dipromosikan melalui sosial media, media massa, brosur, ataupun dicetak pada baliho kampus.

\section{B. Metode Pengembangan Sistem}

Metode pengembangan sistem yang dimanfaatkan dalam membuat aplikasi ini adalah metode berorientasi objek yang direpresentasikan melalui Unified Modeling Languange (UML). Metode ini berusaha mengembangkan aplikasi berdasarkan abstraksi objek-objek yang ada di lingkungan nyata. Metode berorientasi objek cocok untuk diimplementasikan di aplikasi yang akan dibuat, karena membuat modifikasi aplikasi menjadi lebih fleksibel dan mudah. Android Studio sendiri menggunakan bahasa pemrograman Java yang mendukung pemrograman berorientasi objek/ Object-Oriented Programming (OOP).

\section{Alat Bantu Pengembangan Sistem}

Aplikasi ini dibuat dengan menggunakan alat bantu pengembangan sistem UML, yaitu bahasa formal pemodelan aplikasi dan proses bisnis yang umumnya dipakai di pendekatan 
berorientasi objek. Dalam pembuatan aplikasi PMB ini, diagram-diagram UML yang digunakan diantaranya use case diagram, activity diagram, sequence diagram, sekaligus class diagram.

\section{HASIL DAN PEMBAHASAN}

\section{A. Analisa Kebutuhan}

Tahapan analisa kebutuhan dilakukan untuk menentukan kebutuhan dari aplikasi yang akan dibuat. Kebutuhan fungsional pada penelitian ini diwakili dengan menggunakan use case diagram.

1) Analisa kebutuhan fungsional: kebutuhan-kebutuhan fungsional yang terdapat pada aplikasi PMB yang dibuat adalah sebagai berikut :

- Pengguna camaba STMIK Atma Luhur dengan menggunakan aplikasi PMB dapat mendaftar, memeriksa status pendaftaran, mengubah data pendaftaran, mengunduh kartu wawancara dan kuitansi pembayaran, melihat pengumuman, melihat informasi kampus (fasilitas, profil, program studi (prodi), dan lokasi), melihat biaya pendaftaran, dan melihat panduan pendaftaran. Selain itu juga camaba dapat menerima notifikasi apabila ada pengumuman baru, pesan siaran, dan pendaftarannya ditanggapi admin.

- Admin/ panitia PMB STMIK Atma Luhur dengan menggunakan aplikasi PMB dapat login, logout, memasang pengumuman, mengirimkan pesan siaran, mengganti gelombang pendaftaran, melihat daftar pendaftar, memverifikasi pendaftaran, dan mengunduh berkas yang diunggah camaba. Selain itu panitia dapat menerima notifikasi apabila ada pendaftar baru atau pendaftar yang telah ada mengubah data pendaftaran mereka.

2) Analisis sistem berjalan: Saat penelitian ini dibuat, terdapat tiga cara yang dapat dilakukan camaba STMIK Atma Luhur untuk mendaftar, yaitu dengan datang langsung ke bagian informasi, melalui Google Form, atau melalui WhatsApp ke panitia PMB. Pada penelitian ini, hanya akan dibahas cara yang pertama, yaitu mula-mula camaba mendatangi bagian informasi STMIK Atma Luhur dan menanyakan tata cara pendaftaran. Camaba kemudian membayar uang pendaftaran dan melengkapi form pendaftaran. Setelah itu camaba menyerahkan form pendaftaran, bukti pembayaran, serta fotokopi nilai rapor terakhir kepada panitia PMB. Panitia PMB selanjutnya mengentri data camaba ke sistem informasi PMB berbasis desktop berdasarkan form yang diserahkan dan mencetak kartu wawancara sekaligus kuitansi pembayaran pendaftaran. Kedua berkas ini kemudian diserahkan kepada camaba dan camaba dihimbau untuk datang kembali ke kampus berdasarkan jadwal yang tertera di kartu wawancara untuk pengarahan. Gambar 2 menunjukkan activity diagram proses PMB yang berjalan.

\section{B. Rancangan Sistem}

Rancangan sistem dalam membuat aplikasi PMB diantaranya relasi yang ada pada aktor dengan sistem dirancang menggunakan use case diagram, gambaran kelakuan sistem menggunakan activity diagram dan sequence diagram. Class diagram digunakan sebagai representasi kelas-kelas yang terdapat pada sistem.

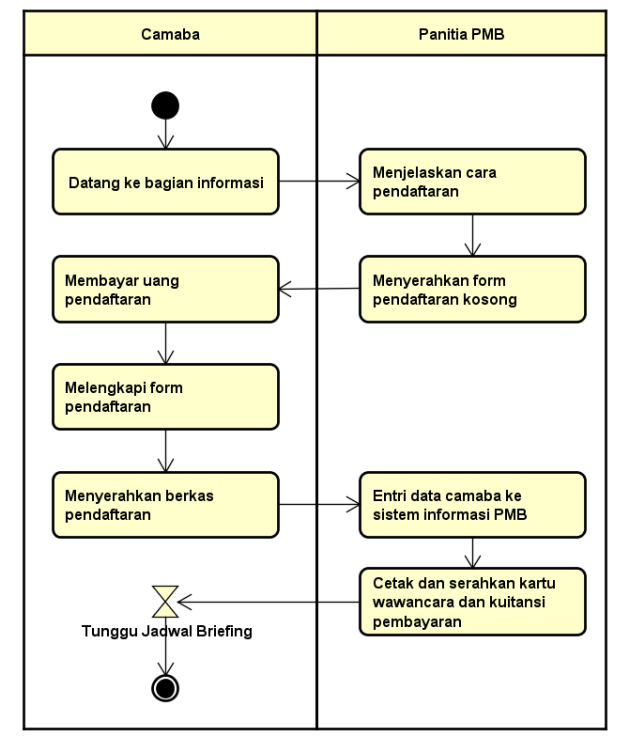

Gambar 2. Activity Diagram Sistem Berjalan

1) Use case diagram: Gambar 3 merupakan use case diagram dari aplikasi PMB yang diusulkan pada penelitian ini.

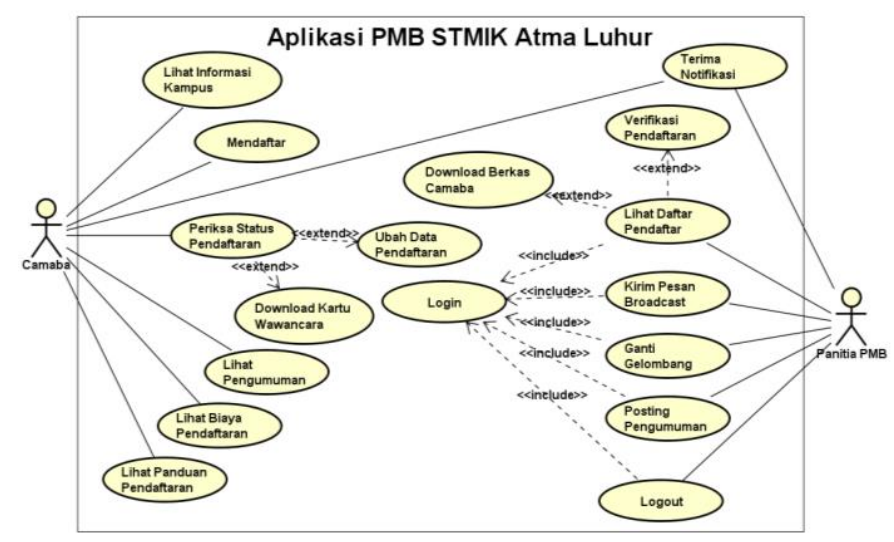

Gambar 3. Use Case Diagram Aplikasi PMB STMIK Atma Luhur

2) Activity Diagram: Berbagai aliran fungsi yang ada pada aplikasi yang dibuat digambarkan menggunakan activity diagram. Tiga dari beberapa activity diagram yang ada di pembuatan aplikasi PMB antara lain activity diagram pendaftaran camaba, verifikasi pembayaran, dan unduh kartu wawancara.

a) Activity diagram pendaftaran: Gambar 4 menunjukkan activity diagram pendaftaran dari aplikasi PMB yang dibuat. Mula-mula camaba memilih menu "Daftar Sekarang", kemudian aplikasi menampilkan halaman pendaftaran. Camaba selanjutnya mengisikan data di form seperti Nomor Induk Kependudukan (NIK), nama, nomor 
ponsel, dan sebagainya. Setelah itu camaba mengunggah berkas berupa foto bukti pembayaran pendaftaran dan foto nilai ratarata rapor terbaru. Camaba kemudian mengetuk tombol "DAFTAR" dan aplikasi akan menyimpan data pendaftaran tersebut ke database. Aplikasi dengan menggunakan FCM akan mengirimkan notifikasi ke panitia PMB yang telah login pada aplikasi ini. Akhirnya camaba dialihkan ke halaman periksa status pendaftaran dan menunggu tanggapan dari panitia PMB.

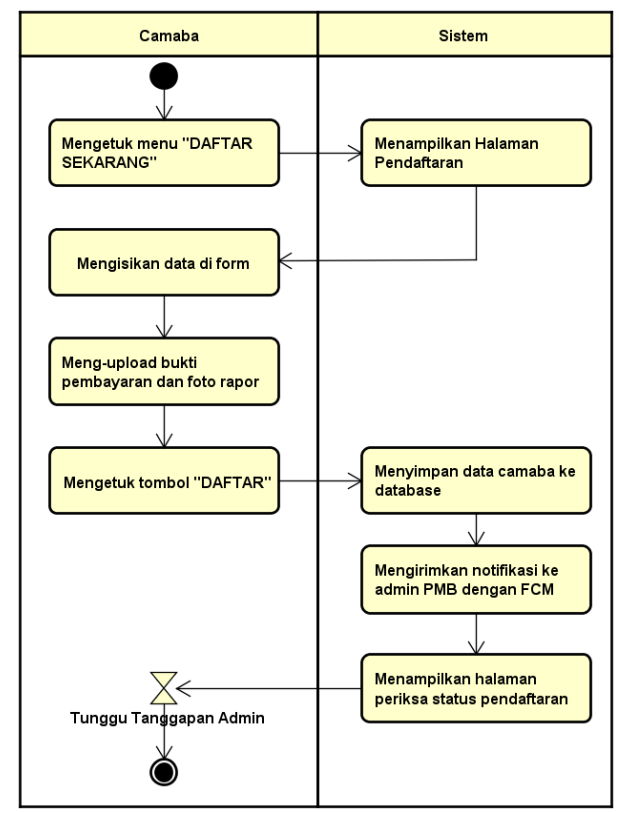

Gambar 4. Activity Diagram Pendaftaran

b) Activity diagram verifikasi pendaftaran: Gambar 5 adalah activity diagram verifikasi pendaftaran dari aplikasi PMB yang dibuat. Pertama-tama admin, yaitu panitia PMB yang telah login memilih menu "Verifikasi Pendaftaran", kemudian aplikasi menampilkan halaman cek daftar pendaftar dan admin melakukan penyaringan berdasarkan tahun ajar, gelombang, dan status pendaftaran. Admin selanjutnya memilih salah satu pendaftar dan aplikasi menampilkan halaman rincian pendaftaran tersebut sesuai data di database. Admin kemudian memeriksa kebenaran data yang diisi camaba dan mengganti statusnya, memberi komentar, dan menginput nilai rapor ratarata. Setelah itu admin mengunggah kartu wawancara dan kuitansi pembayaran serta mengetuk tombol "UBAH". Data camaba di database MySQL akan diperbarui sekaligus disalin ke database ORACLE sehingga sinkron dengan sistem PMB desktop yang telah ada. Pada akhirnya, notifikasi akan dikirimkan ke camaba terkait dan admin diarahkan kembali ke halaman cek daftar pendaftar dengan penyaringan sebelumnya.

c) Activity diagram unduh kartu wawancara: Gambar 6 merupakan activity diagram unduh kartu wawancara dari aplikasi PMB yang dibuat. Pada halaman cek status, camaba menginput nomor Hand Phone (HP) yang digunakan saat mendaftar, lalu mengetuk tombol "CEK STATUS" dan aplikasi akan menampilkan daftar pendaftaran dengan nomor HP tersebut dari database. Camaba kemudian memilih satu di antara pendaftaran tersebut dan aplikasi akan menampilkan halaman perubahan camaba. Akhirnya camaba mengetuk tombol "UNDUH BUKTI VERIFIKASI" dan proses unduh kartu wawancara akan dijalankan. Setelah proses unduh selesai, kartu wawancara akan ditambahkan di album foto camaba.

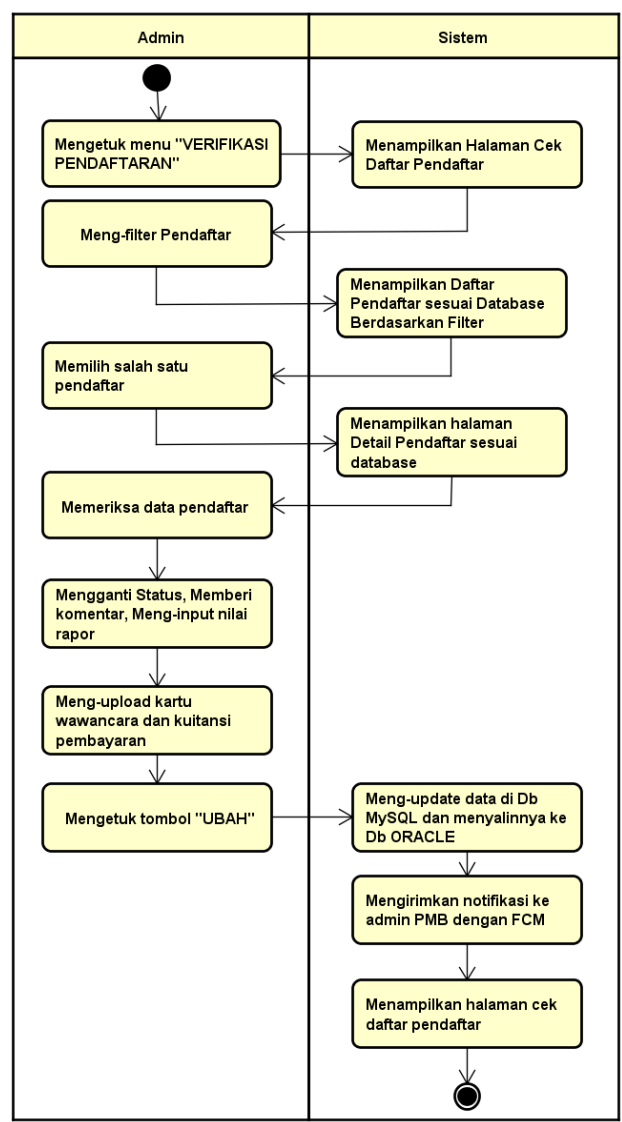

Gambar 5. Activity Diagram Verifikasi Pendaftaran

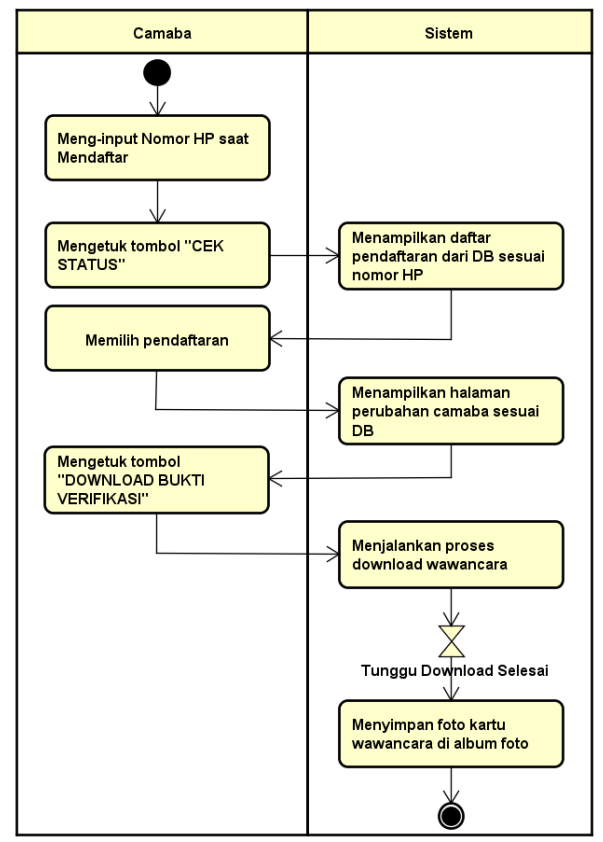

Gambar 6. Activity Diagram Unduh Kartu Wawancara 
3) Sequence Diagram: Aliran fungsi yang ada pada use case digambarkan dengan sequence diagram. Selain itu sequence diagram memaparkan urutan relasi objek yang tersusun pada urutan waktu tertentu. Tiga dari beberapa sequence diagram yang ada di pembuatan aplikasi PMB antara lain sequence diagram pendaftaran camaba, verifikasi pendaftaran, dan unduh kartu wawancara.

a) Sequence diagram pendaftaran: Gambar 7 adalah sequence diagram pendaftaran camaba yang menunjukkan aliran tahapan-tahapan camaba dalam melakukan pendaftaran dengan menggunakan aplikasi yang dibuat.

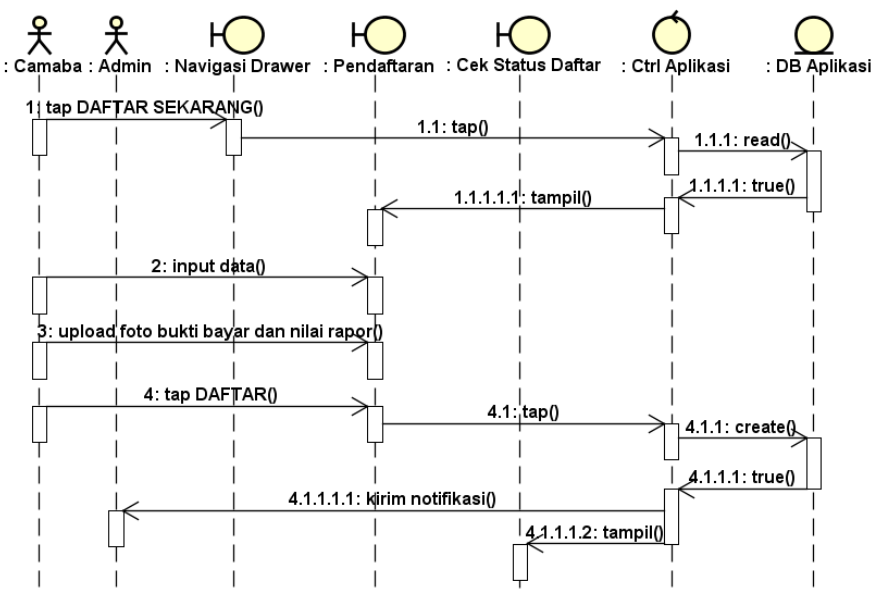

Gambar 7. Sequence Diagram Pendaftaran

b) Sequence diagram verifikasi pendaftaran: Gambar 8 adalah sequence diagram verifikasi pendaftaran yang menunjukkan aliran tahapan-tahapan admin dalam memverifikasi pendaftaran camaba dengan menggunakan aplikasi yang dibuat..

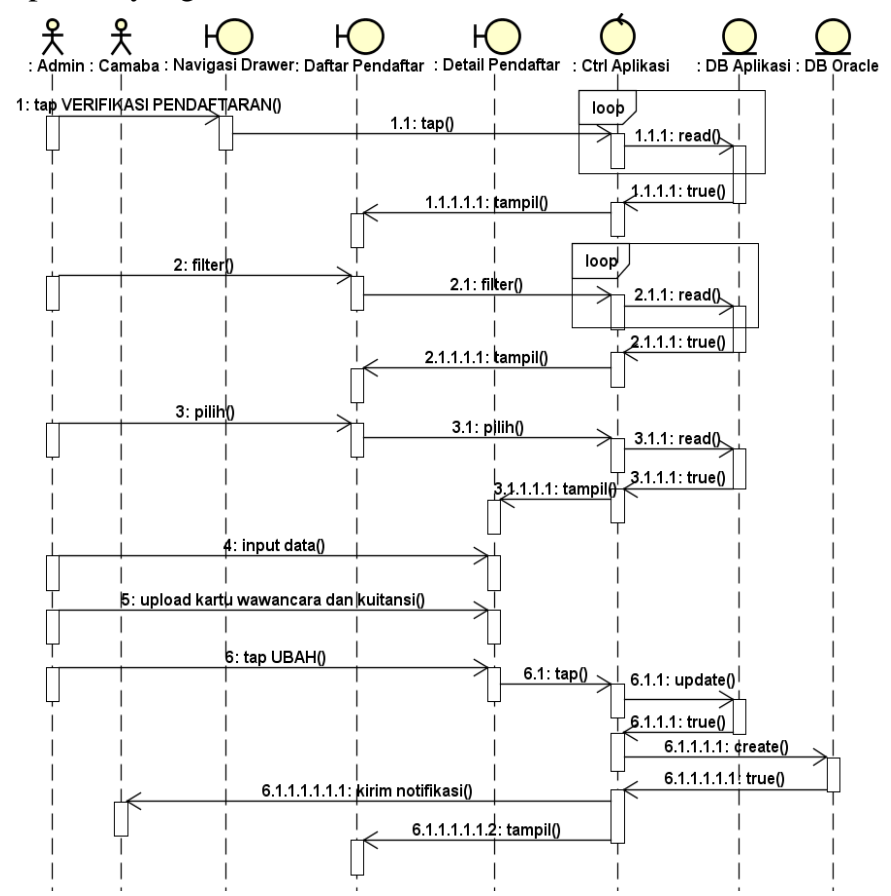

Gambar 8. Sequence Diagram Verifikasi Pendaftaran c) Sequence diagram unduh kartu wawancara: Gambar 9 adalah sequence diagram unduh kartu wawancara yang menunjukkan aliran tahapan-tahapan camaba dalam mengunduh kartu wawancara dengan menggunakan aplikasi yang dibuat..

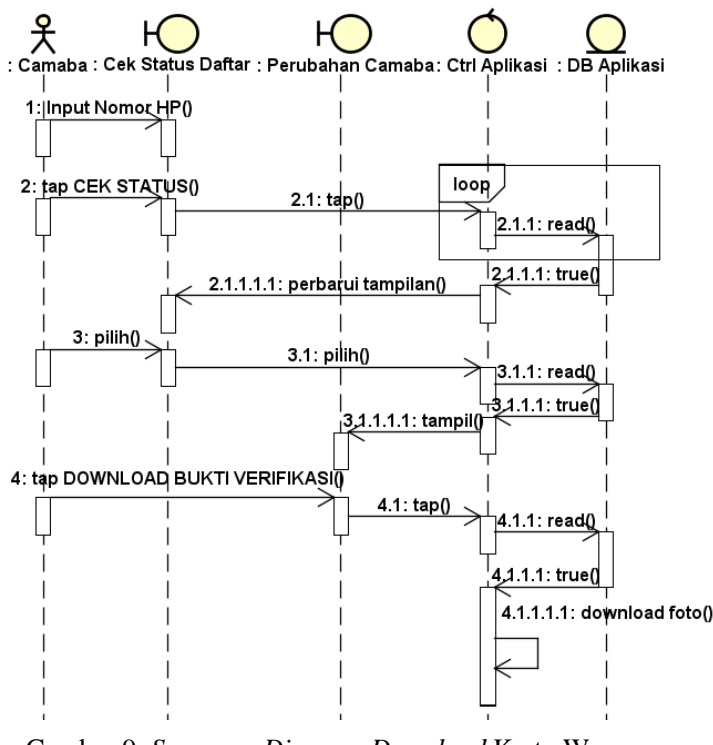

Gambar 9. Sequence Diagram Download Kartu Wawancara

4) Class Diagram: Hubungan antar kelas pada aplikasi yang meliputi kelas, atribut, dan metode digambarkan dengan class diagram. Seluruh sifat dari visibilitas atribut kelas yang terdapat pada database adalah pribadi yang berarti nilainya tak dapat diambil langsung sedangan visibilitas metode yang ada adalah publik. Gambar 10 adalah class diagram dari aplikasi PMB yang dibuat.

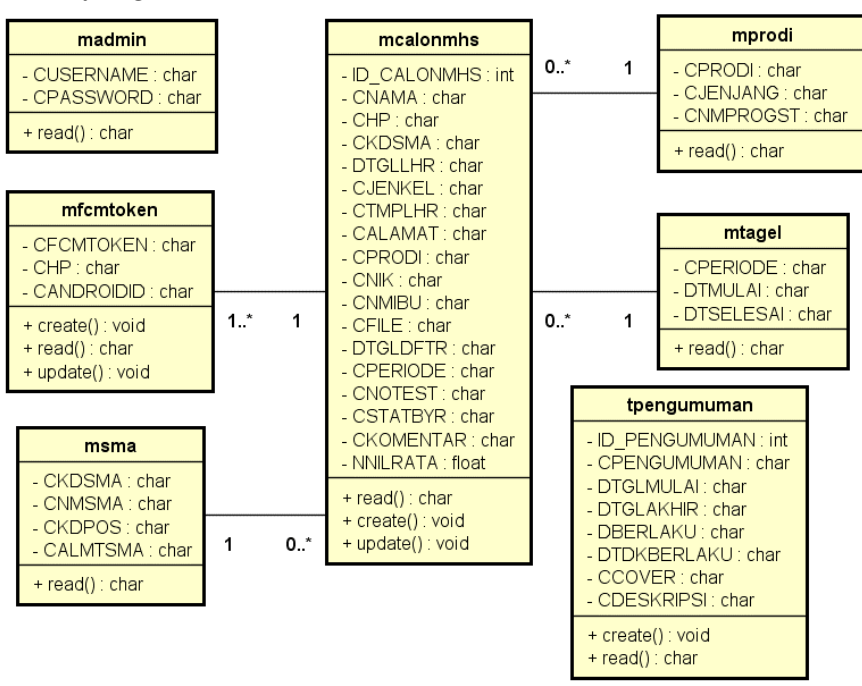

Gambar 10. Class Diagram Aplikasi PMB

\section{Implementasi Sistem}

Pada tahap implementasi sistem akan dilakukan implementasi dari aplikasi PMB yang telah dibuat di tahap rancangan sistem untuk dimanfaatkan pada STMIK Atma Luhur. 
1) Tampilan layar: Pada tampilan layar, akan dilakukan pembahasan mengenai halaman-halaman yang ada pada aplikasi beserta fungsi dari halaman tersebut.

a) Tampilan layar pengumuman: Gambar 11 kiri menunjukkan halaman pengumuman terkait PMB sekaligus beranda dari aplikasi dan kanan menunjukkan halaman rincian pengumuman.

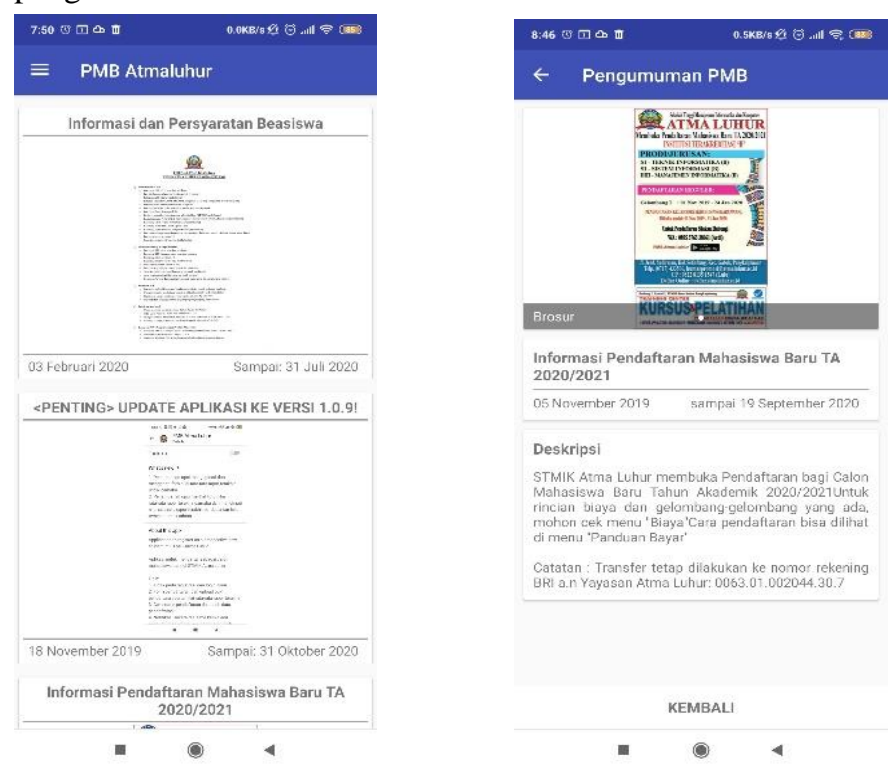

Gambar 11. (kiri) Tampilan Layar Pengumuman (kanan) Tampilan Layar Rincian Pengumuman

b) Tampilan layar navigasi drawer: Gambar 12 menunjukkan halaman drawer navigasi aplikasi yang dapat diakses dengan mengetuk ikon tiga garis pada halaman pengumuman.
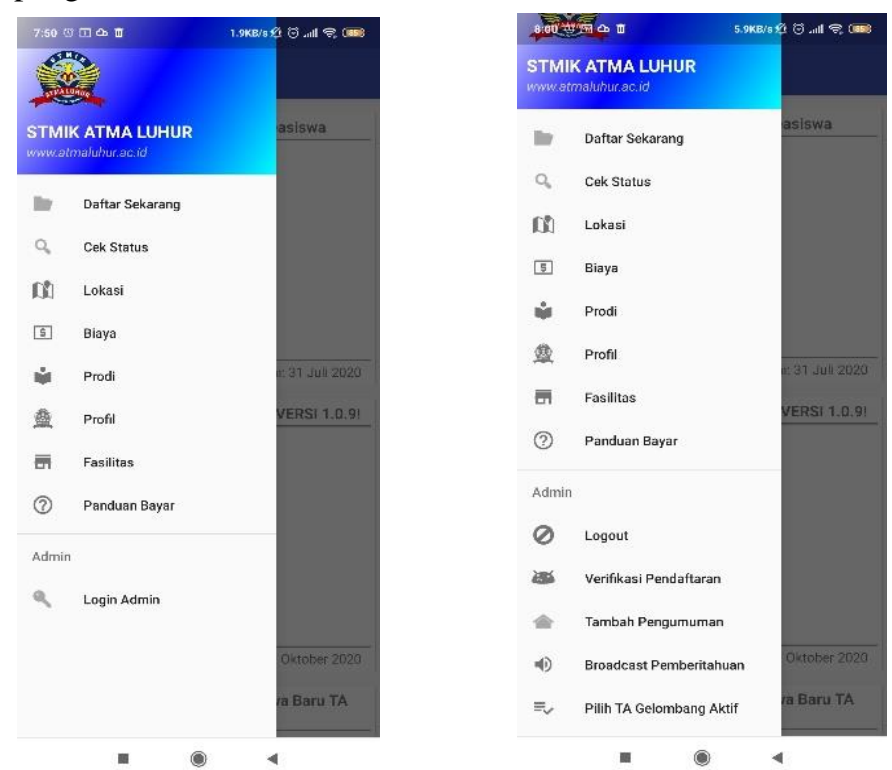

Gambar 12. Tampilan Layar Navigasi Drawer (kiri) Camaba (kanan) Admin

c) Tampilan layar login: Gambar 13 menunjukkan halaman login yang dapat diakses dengan mengetuk "Login
Admin" pada halaman drawer navigasi. Pengguna yang telah login dapat mengakses menu-menu khusus admin pada aplikasi.

d) Tampilan layar pendaftaran: Gambar 14 menunjukkan halaman pendaftaran yang dapat diakses dengan mengetuk "Daftar Sekarang" di halaman drawer navigasi dan digunakan oleh camaba untuk mendaftar di STMIK Atma Luhur.
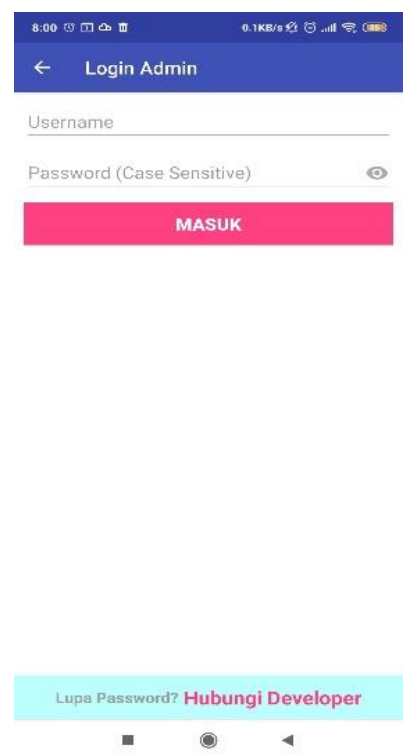

Gambar 13. Tampilan Layar Login

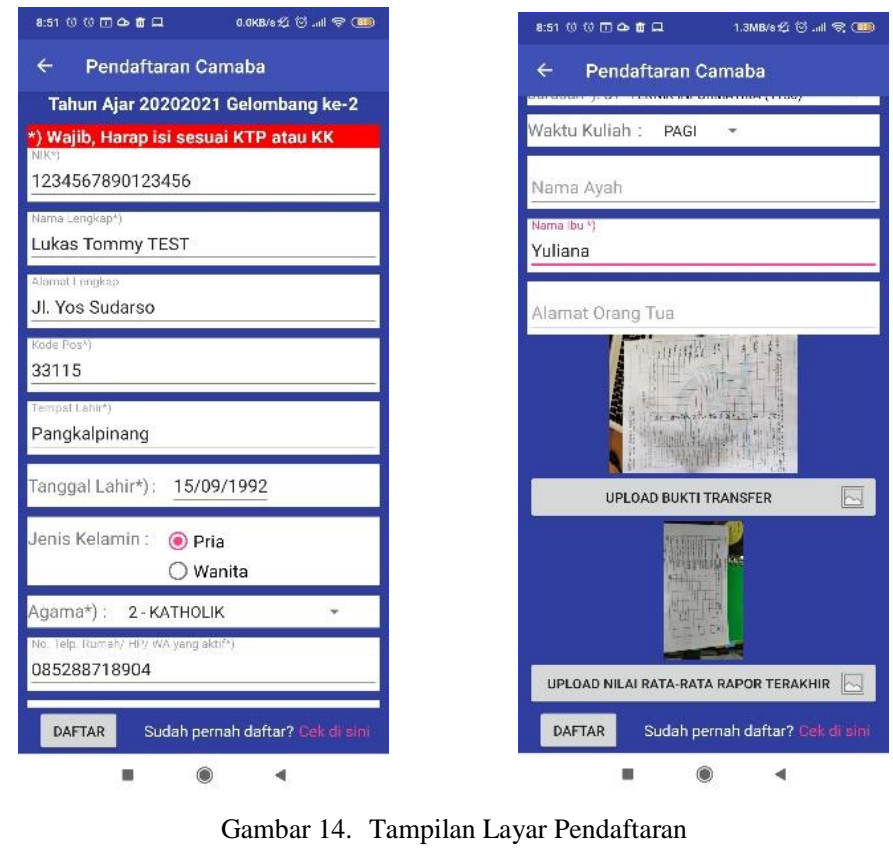

e) Tampilan layar cek status pendaftaran: Gambar 15 menunjukkan halaman cek status pendaftaran yang dapat diakses dengan mengetuk "Cek Status" di halaman drawer navigasi dan digunakan oleh camaba untuk mengecek status pendaftarannya.

f) Tampilan layar profil kampus: Gambar 16 menunjukkan halaman profil kampus yang dapat diakses 
dengan mengetuk "Profil" di halaman drawer navigasi dan digunakan camaba untuk melihat profil dari kampus STMIK Atma Luhur.

g) Tampilan layar fasilitas kampus: Gambar 17 menunjukkan halaman fasilitas kampus yang dapat diakses dengan mengetuk "Fasilitas" di halaman drawer navigasi dan digunakan camaba untuk mendapatkan informasi terkait fasilitas yang ada di STMIK Atma Luhur.

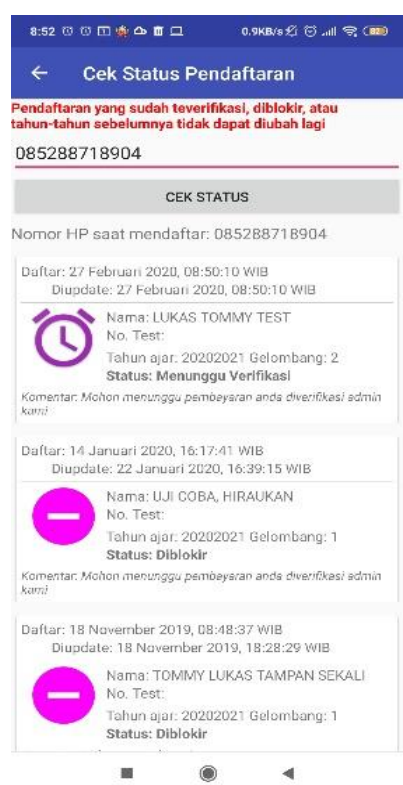

Gambar 15. Tampilan Layar Cek Pendaftaran
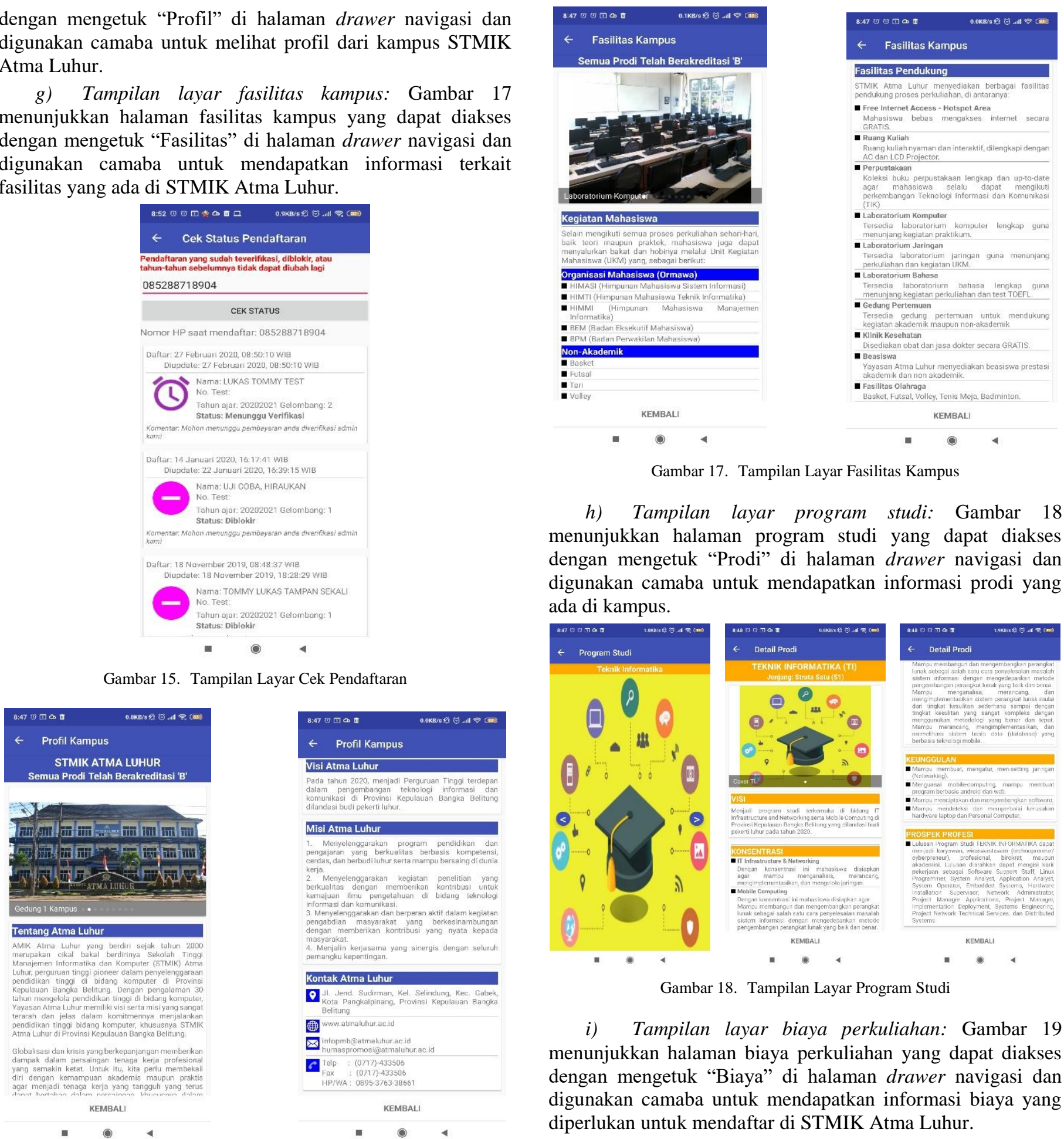

h) Tampilan layar program studi: Gambar 18 menunjukkan halaman program studi yang dapat diakses dengan mengetuk "Prodi" di halaman drawer navigasi dan digunakan camaba untuk mendapatkan informasi prodi yang ada di kampus.
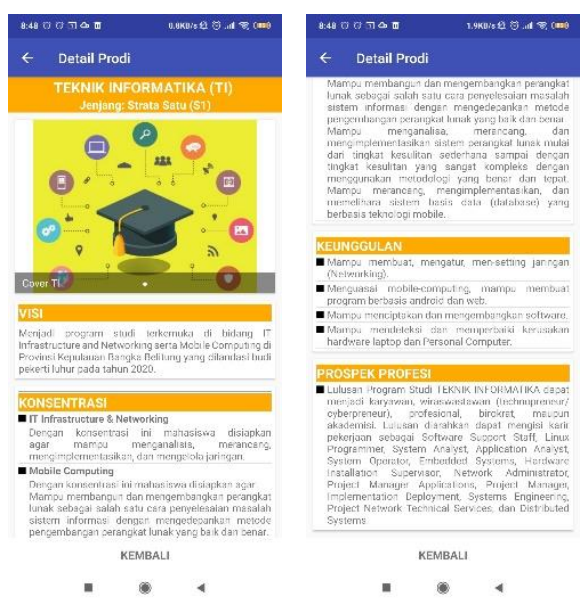

Gambar 18. Tampilan Layar Program Studi

i) Tampilan layar biaya perkuliahan: Gambar 19 menunjukkan halaman biaya perkuliahan yang dapat diakses dengan mengetuk "Biaya" di halaman drawer navigasi dan digunakan camaba untuk mendapatkan informasi biaya yang diperlukan untuk mendaftar di STMIK Atma Luhur.

Gambar 16. Tampilan Layar Profil Kampus 

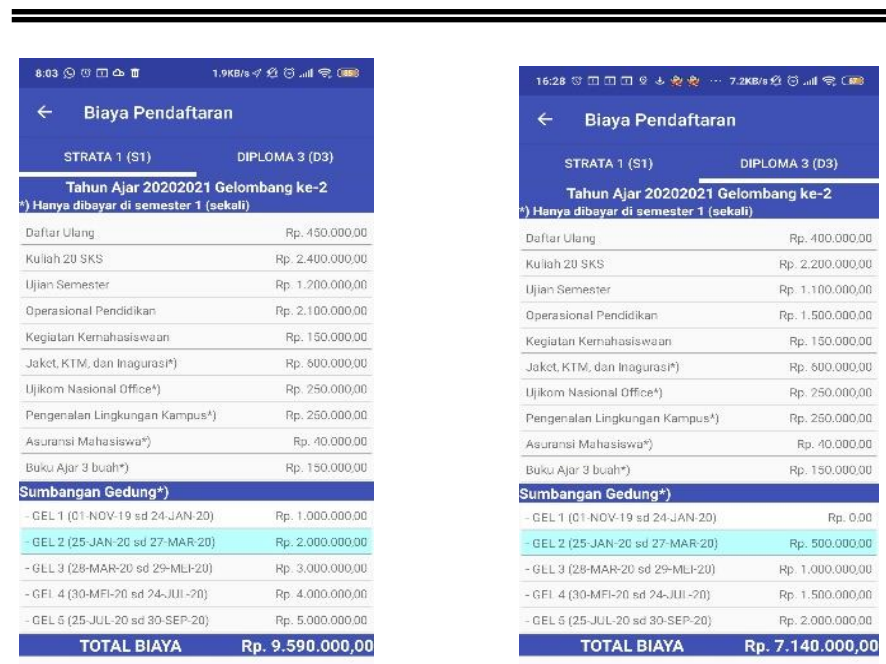

Gambar 19. Tampilan Layar Biaya Perkuliahan Jenjang (kiri) S1-Strata Satu (kanan) D3-Diploma Tiga

j) Tampilan layar lokasi kampus: Gambar 20 menunjukkan halaman lokasi kampus yang dapat diakses dengan mengetuk "Lokasi" di halaman drawer navigasi dan digunakan camaba untuk mengetahui lokasi kampus STMIK Atma Luhur dan lokasi mereka saat ini dengan Google Map terintegrasi.

k) Tampilan layar panduan pendaftaran: Gambar 21 menunjukkan halaman panduan pendaftaran yang dapat diakses dengan mengetuk "Panduan Bayar" di halaman drawer navigasi dan digunakan camaba untuk mengetahui cara melakukan pendaftaran di STMIK Atma Luhur dengan menggunakan aplikasi.

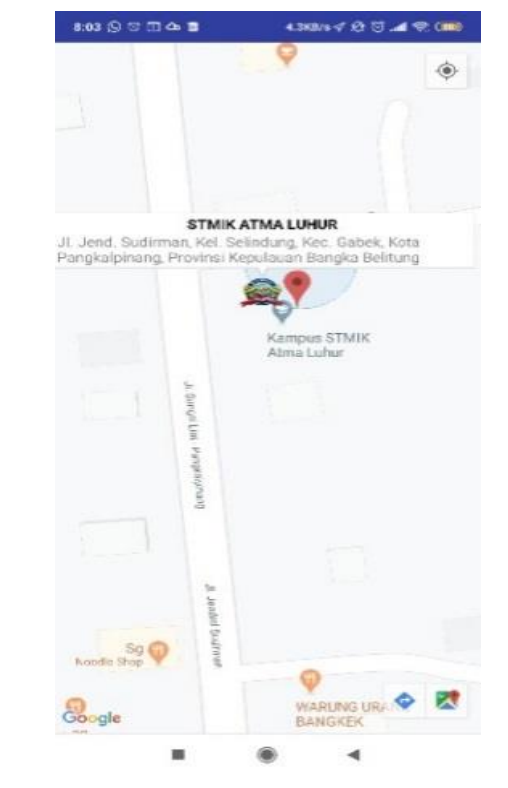

Gambar 20. Tampilan Layar Lokasi Kampus

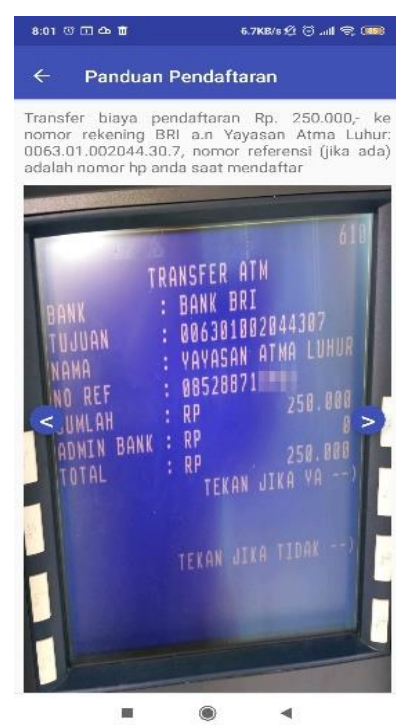

Gambar 21. Tampilan Layar Panduan Pendaftaran

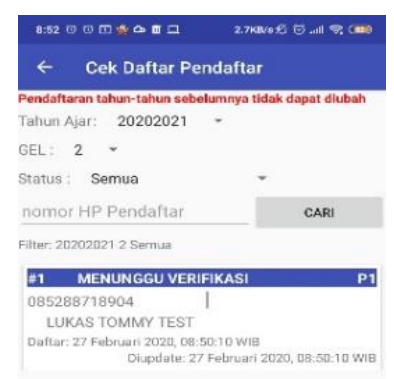

Gambar 22. Tampilan Layar Cek Daftar Pendaftar

l) Tampilan layar cek daftar pendaftar: Gambar 22 menunjukkan halaman periksa cek pendaftaran yang dapat diakses dengan mengetuk "Verifikasi Pendaftaran" di halaman drawer navigasi dan digunakan admin untuk mencari sekaligus menyaring daftar pendaftar yang mendaftar dengan menggunakan aplikasi usulan.

m) Tampilan layar verifikasi pendaftaran: Gambar 23 menunjukkan halaman verifikasi pendaftaran yang dapat diakses dengan mengetuk salah satu pendaftar di halaman cek daftar pendaftar. Halaman ini digunakan admin untuk memeriksa biodata camaba, berkas yang diunggah, sekaligus memverifikasi pendaftaran tersebut. Gambar 24 menunjukkan data camaba di database MySQL dan Gambar 25 menunjukkan data di database Oracle setelah admin memverifikasi pendaftaran ini. 

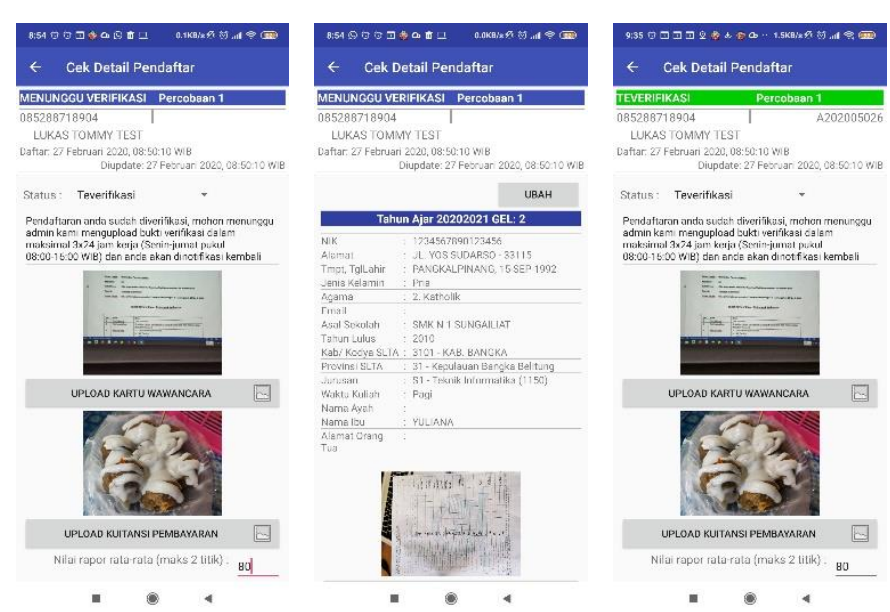

Gambar 23. Tampilan Layar Verifikasi Pendaftaran (kiri dan tengah) Sebelum Diverifikasi (kanan) Setelah Diverifikasi

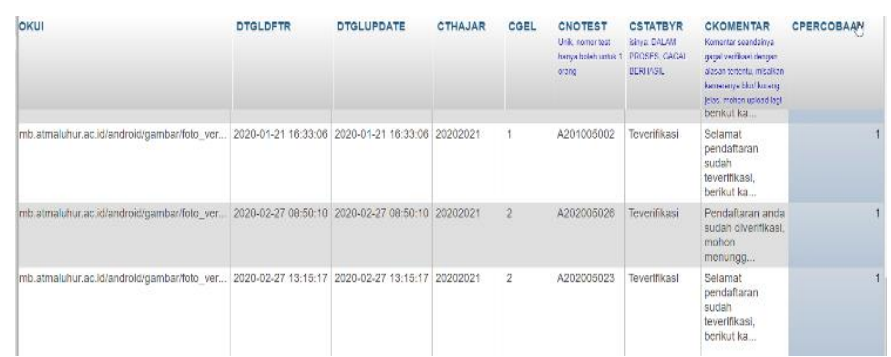

Gambar 24. Data Camaba di Database MySQL

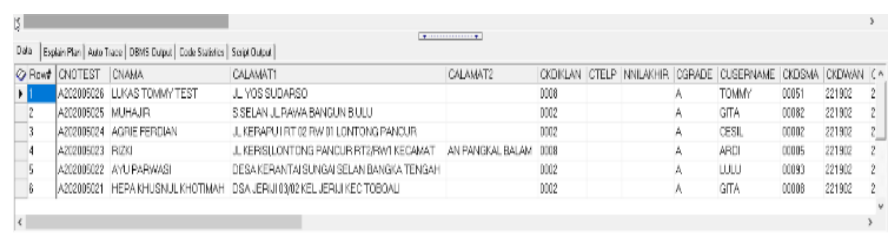

Gambar 25. Data Camaba di Database Oracle

n) Tampilan layar ubah data camaba: Gambar 26 menunjukkan halaman ubah data camaba yang dapat diakses dengan mengetuk salah satu pendaftaran di halaman cek status pendaftaran. Halaman ini digunakan camaba untuk mengganti data pendaftaran sekaligus foto yang diunggah selama statusnya bukan teverifikasi atau diblokir. Selain itu setelah diverifikasi admin, camaba dapat mengunduh kartu wawancara dan kuitansi pembayaran.

o) Tampilan layar broadcast pemberitahuan: Gambar 27 menunjukkan halaman broadcast pemberitahuan yang dapat diakses admin dengan mengetuk "Broadcast Pemberitahuan" di halaman drawer navigasi. Halaman ini digunakan untuk mengirimkan pesan notifikasi terkait PMB ke seluruh pengguna yang memasang aplikasi yang dibuat.
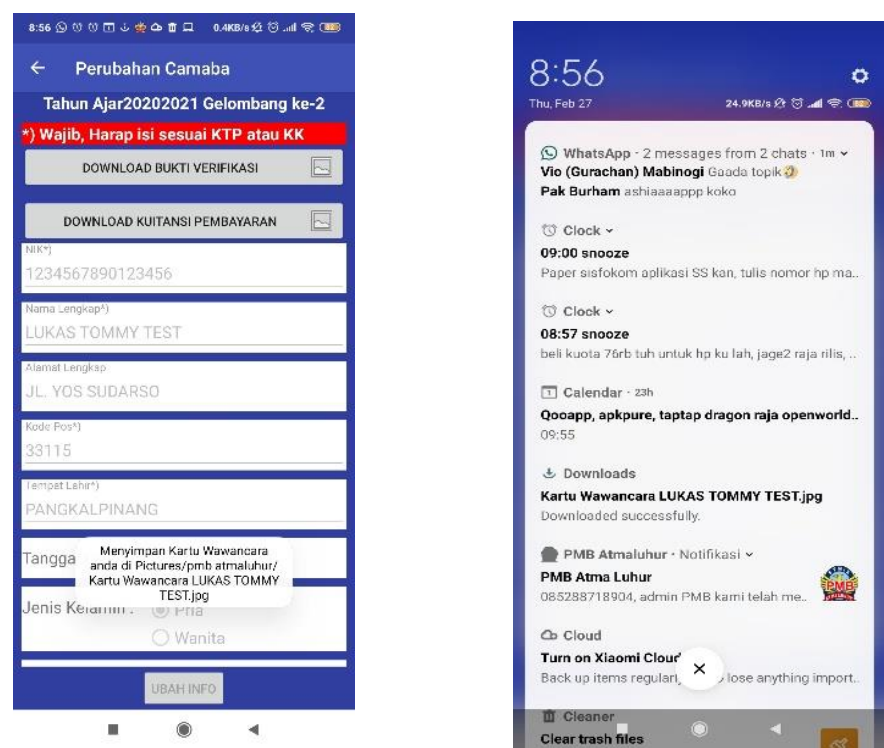

Gambar 26. Tampilan Layar (kiri) Ubah Data Camaba (kanan) Notifikasi Unduhan Sukses

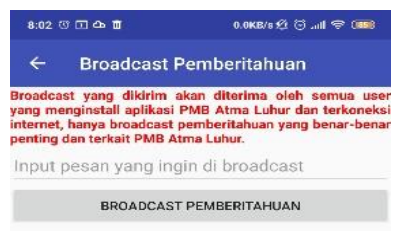

Gambar 27. Tampilan Layar Broadcast Pemberitahuan

p) Tampilan layar tambah pengumuman: Gambar 28 menunjukkan halaman tambah pengumuman yang dapat diakses admin dengan mengetuk "Tambah Pengumuman" di halaman drawer navigasi. Halaman ini digunakan untuk menambahkan pengumuman terkait PMB dan kemudian diumumkan pada aplikasi yang dibuat.

q) Tampilan layar pilih periode aktif: Gambar 29 menunjukkan halaman pilih periode aktif yang dapat diakses admin dengan mengetuk "Pilih TA Gelombang Aktif" di halaman drawer navigasi. Halaman ini digunakan untuk mengganti tahun ajar dan gelombang yang sedang aktif pada aplikasi PMB. 


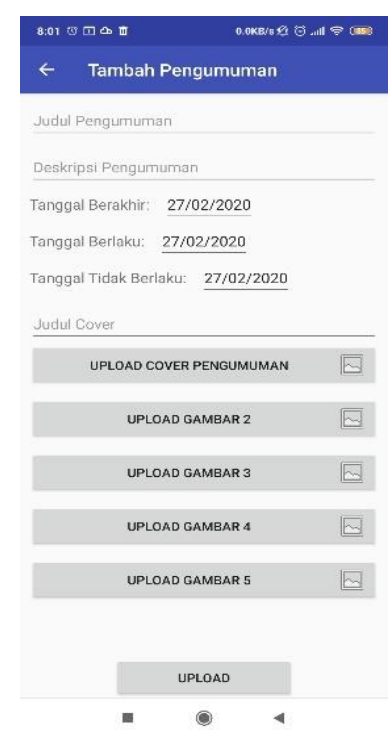

Gambar 28. Tampilan Layar Tambah Pengumuman

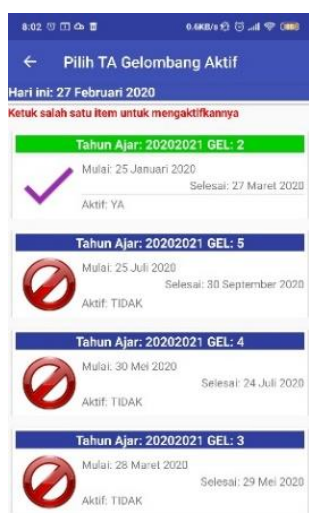

Gambar 29. Tampilan Layar Pilih Periode Aktif
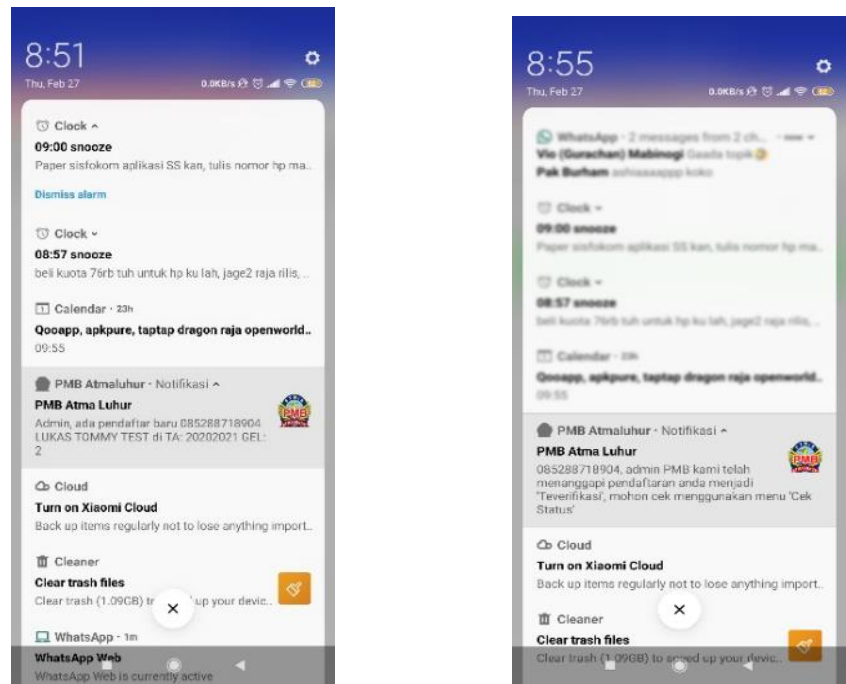

Gambar 30. Tampilan Layar Push Notification ketika (kiri) Camaba Baru Mendaftar (kanan) Admin Menanggapi Pendaftaran r) Tampilan layar push notification: Gambar 30 menunjukkan contoh push notification pada aplikasi yang dikirim dan diterima dengan menggunakan FCM.

2) Pengujian Aplikasi: Fungsionalitas dari aplikasi yang dibuat akan diuji dengan model pengujian black box testing, selain itu tingkat kepuasan responden atas aplikasi diukur dengan menggunakan Skala Likert.

a) Black box testing: Tabel I menunjukkan output dari black box testing yang telah dilakukan terhadap aplikasi yang dibuat.

TABEL I. OUTPUT BLACK BOX TESTING

\begin{tabular}{|c|c|c|c|}
\hline No & Skenario Pengujian & Hasil yang diharapkan & Ket. \\
\hline 1 & $\begin{array}{l}\text { Saat mengisi form } \\
\text { pendaftaran terdapat isian } \\
\text { wajib namun tidak diisi dan } \\
\text { tombol DAFTAR diketuk }\end{array}$ & $\begin{array}{l}\text { Isian wajib yang belum } \\
\text { diisi disoroti oleh aplikasi }\end{array}$ & Sesuai \\
\hline 2 & $\begin{array}{l}\text { Semua isian wajib terisi pada } \\
\text { form pendaftaran dan tombol } \\
\text { DAFTAR diketuk }\end{array}$ & $\begin{array}{l}\text { Data camaba tersimpan di } \\
\text { database, pengguna } \\
\text { dialihkan ke halaman cek } \\
\text { status, notifikasi dikirim ke } \\
\text { admin PMB, dan pengguna } \\
\text { akan menerima notifikasi } \\
\text { jika pendaftaran dengan } \\
\text { nomor HP yang } \\
\text { didaftarkan ditanggapi } \\
\text { admin }\end{array}$ & Sesuai \\
\hline 3 & \begin{tabular}{lr}
\multicolumn{2}{l}{ Ponsel yang sama digunakan } \\
untuk mendaftar lebih dari 2 \\
kali dan pendaftar \\
sebelumnya \\
teverifikasi
\end{tabular} & $\begin{array}{l}\text { Pendaftaran ditolak dengan } \\
\text { menampilkan pesan } \\
\text { kesalahan }\end{array}$ & Sesuai \\
\hline 4 & $\begin{array}{l}\text { Mengisi nomor HP yang } \\
\text { terdaftar dan mengetuk } \\
\text { tombol CEK STATUS di } \\
\text { halaman cek status }\end{array}$ & $\begin{array}{l}\text { Menampilkan daftar } \\
\text { pendaftaran dengan nomor } \\
\text { HP tersebut dan pengguna } \\
\text { akan menerima notifikasi } \\
\text { apabila pendaftaran dengan } \\
\text { nomor HP yang diisi } \\
\text { ditanggapi admin }\end{array}$ & Sesuai \\
\hline 5 & $\begin{array}{l}\text { Mengetuk pendaftaran } \\
\text { dengan status Menunggu } \\
\text { verifikasi atau Gagal di } \\
\text { halaman cek status }\end{array}$ & $\begin{array}{l}\text { Menampilkan halaman } \\
\text { ubah data camaba dimana } \\
\text { datanya dapat diubah }\end{array}$ & Sesuai \\
\hline 6 & $\begin{array}{l}\text { Mengetuk pendaftaran } \\
\text { dengan status teverifikasi, } \\
\text { diblokir, atau tahun ajar yang } \\
\text { sudah lewat di halaman cek } \\
\text { status }\end{array}$ & $\begin{array}{l}\text { Menampilkan halaman } \\
\text { ubah data camaba dimana } \\
\text { datanya tidak dapat diubah }\end{array}$ & Sesuai \\
\hline 7 & $\begin{array}{l}\text { Mengubah data kemudian } \\
\text { mengetuk tombol UBAH } \\
\text { INFO di halaman ubah data } \\
\text { camaba }\end{array}$ & $\begin{array}{l}\text { Data camaba diperbarui di } \\
\text { database, pengguna } \\
\text { dialihkan ke halaman cek } \\
\text { status, notifikasi dikirim ke } \\
\text { admin PMB, dan pengguna } \\
\text { akan menerima notifikasi } \\
\text { jika pendaftaran dengan } \\
\text { nomor HP tersebut } \\
\text { ditanggapi admin }\end{array}$ & Sesuai \\
\hline 8 & $\begin{array}{lr}\text { Mengetuk } & \text { tombol } \\
\text { DOWNLOAD } & \text { BUKTI } \\
\text { VERIFIKASI } & \text { atau } \\
\text { DOWNLOAD } & \text { KUITANSI } \\
\text { PEMBAYARAN di halaman } \\
\text { ubah data camaba }\end{array}$ & $\begin{array}{l}\text { Proses unduh kartu } \\
\text { wawancara atau kuitansi } \\
\text { pembayaran dijalankan }\end{array}$ & Sesuai \\
\hline 9 & 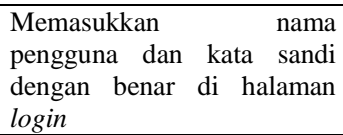 & $\begin{array}{lrr}\text { Beralih } & \text { ke } & \text { halaman } \\
\text { beranda, halaman navigasi } \\
\text { drawer } & \text { menampilkan } \\
\text { menu } & \text { khusus admin, }\end{array}$ & Sesuai \\
\hline
\end{tabular}




\begin{tabular}{|c|c|c|c|}
\hline No & Skenario Pengujian & Hasil yang diharapkan & Ket. \\
\hline & & $\begin{array}{l}\text { pengguna mendapatkan } \\
\text { notifikasi apabila ada } \\
\text { camaba mendaftar ataupun } \\
\text { mengubah datanya }\end{array}$ & \\
\hline 10 & $\begin{array}{l}\text { Menginput pesan } \begin{array}{r}\text { dan } \\
\text { mengetuk }\end{array} \\
\text { BROADCAST } \\
\text { PEMBERITAHUAN } \\
\text { halaman di } \\
\text { pemberitahuan }\end{array}$ & $\begin{array}{l}\text { Notifikasi berisikan pesan } \\
\text { broadcast terkirim ke } \\
\text { seluruh pengguna aplikasi } \\
\text { dan log tersimpan di } \\
\text { database }\end{array}$ & Sesuai \\
\hline 11 & $\begin{array}{lr}\text { Menginput } & \text { data } \\
\text { pengumuman } & \text { kemudian } \\
\text { mengetuk tombol } & \text { UPLOAD } \\
\text { di halaman } & \text { tambah } \\
\text { pengumuman } & \end{array}$ & $\begin{array}{lr}\text { Pengumuman ditambah di } \\
\text { database kemudian } \\
\text { ditampilkan di aplikasi } \\
\text { PMB, selain itu notifikasi } \\
\text { dikirimkan ke seluruh } \\
\text { pengguna }\end{array}$ & Sesuai \\
\hline 12 & $\begin{array}{l}\text { Menyaring pencarian dan } \\
\text { mengetuk tombol CARI di } \\
\text { halaman cek daftar pendaftar }\end{array}$ & $\begin{array}{l}\text { Hanya menampilkan daftar } \\
\text { pendaftar berdasarkan } \\
\text { penyaringan yang dipilih }\end{array}$ & Sesuai \\
\hline 13 & $\begin{array}{l}\text { Memilih salah satu periode di } \\
\text { halaman periode aktif }\end{array}$ & $\begin{array}{l}\text { Tahun ajar dan gelombang } \\
\text { aktif pada aplikasi } \\
\text { diperbarui }\end{array}$ & Sesuai \\
\hline 14 & $\begin{array}{l}\text { Memilih pendaftaran di } \\
\text { halaman cek daftar pendaftar } \\
\text { dimana tahun ajarnya sudah } \\
\text { lewat }\end{array}$ & $\begin{array}{lr}\text { Menampilkan } & \text { halaman } \\
\text { verifikasi pendaftaran } \\
\text { dimana datanya hanya bisa } \\
\text { dibaca }\end{array}$ & Sesuai \\
\hline 15 & $\begin{array}{l}\text { Mengganti status pendaftaran } \\
\text { menjadi Gagal atau Diblokir, } \\
\text { lalu mengetuk tombol UBAH } \\
\text { di halaman verifikasi } \\
\text { pendaftaran }\end{array}$ & $\begin{array}{l}\text { Status pendaftaran camaba } \\
\text { di database diperbarui dan } \\
\text { notifikasi dikirim ke } \\
\text { camaba yang bersangkutan }\end{array}$ & Sesuai \\
\hline 16 & $\begin{array}{l}\text { Mengganti status pendaftaran } \\
\text { menjadi teverifikasi, lalu } \\
\text { mengetuk tombol UBAH di } \\
\text { halaman } \\
\text { pendaftaran }\end{array}$ & $\begin{array}{l}\text { Status pendaftaran camaba } \\
\text { di database diperbarui dan } \\
\text { diberikan nomor test secara } \\
\text { otomatis, data camaba } \\
\text { disalin ke database oracle, } \\
\text { kemudian notifikasi } \\
\text { dikirim ke camaba terkait }\end{array}$ & Sesuai \\
\hline
\end{tabular}

TABEL II. REKAPITULASI KUESIONER

\begin{tabular}{|l|l|c|c|c|c|c|c|}
\hline No & \multicolumn{1}{|c|}{ Soal } & $\begin{array}{c}\mathbf{1} \\
\text { (TS) }\end{array}$ & $\begin{array}{c}\mathbf{2} \\
\text { (KS) }\end{array}$ & $\mathbf{3}$ (S) & $\begin{array}{c}\mathbf{4} \\
\text { (SS) }\end{array}$ & Tot & Rt2 \\
\hline 1 & $\begin{array}{l}\text { Camaba } \\
\text { mendaftar di } \\
\text { STMIK Atma } \\
\text { Luhur menjadi } \\
\text { lebih mudah dan } \\
\text { efisien }\end{array}$ & 17 & 34 & 197 & 227 & 475 & $\mathbf{3 , 3 3}$ \\
\hline 2 & $\begin{array}{l}\text { Aplikasi } \\
\text { memudahkan } \\
\text { dan } \\
\text { mempercepat } \\
\text { pekerjaan } \\
\text { panitia PMB }\end{array}$ & 14 & 26 & 152 & 283 & 475 & $\mathbf{3 , 4 8}$ \\
\hline 3 & $\begin{array}{l}\text { Informasi terkait } \\
\text { PMB seperti } \\
\text { pengumuman, } \\
\text { biaya } \\
\text { perkuliahan, dan } \\
\text { fasilitas STMIK } \\
\text { Atma Luhur } \\
\text { pada adikasi } \\
\text { menarik, mudah } \\
\text { diakses, dan } \\
\text { jelas }\end{array}$ & & 31 & 227 & 194 & 475 & $\mathbf{3 , 2 5}$ \\
\hline 4 & $\begin{array}{l}\text { Aplikasi dapat } \\
\text { dioperasikan } \\
\text { dengan mudah }\end{array}$ & 16 & 23 & 193 & 243 & 475 & $\mathbf{3 , 4 0}$ \\
\hline
\end{tabular}

\begin{tabular}{|l|c|c|c|c|c|c|c|}
\hline No & Soal & $\begin{array}{c}\mathbf{1} \\
\text { (TS) }\end{array}$ & $\begin{array}{c}\mathbf{2} \\
\text { (KS) }\end{array}$ & $\mathbf{3}$ (S) & $\begin{array}{c}\mathbf{4} \\
\text { (SS) }\end{array}$ & Tot & Rt2 \\
\hline 5 & $\begin{array}{l}\text { Notifikasi yang } \\
\text { dikirimkan jelas } \\
\text { dan diterima } \\
\text { tepat waktu }\end{array}$ & 9 & 21 & 184 & 261 & 475 & $\mathbf{3 , 4 7}$ \\
\hline Total Rata-Rata & $\mathbf{7 9}$ & $\mathbf{1 3 5}$ & $\mathbf{9 5 3}$ & $\mathbf{1 2 0 8}$ & $\mathbf{2 3 7 5}$ & $\mathbf{3 , 3 9}$ \\
\hline
\end{tabular}

Keterangan: TS : Tidak Setuju, KS : Kurang Setuju, S : Setuju, SS : Sangat Setuju, Tot : Total, Rat2 : Rata-rata

b) Skala Likert: Tabel II menunjukkan rekapitulasi dari kuesioner terkait aplikasi PMB yang dibuat dan disebarkan kepada 475 responden (465 orang camaba dan 10 orang panitia PMB) yang kemudian diukur dengan Skala Likert. Skala likert merupakan skala penelitian untuk mengukur sikap dan pendapat responden yang diminta untuk melengkapi kuesioner dengan maksud menunjukkan tingkat persetujuan mereka terhadap serangkaian pertanyaan. Berdasarkan kuesioner yang telah direkap, secara keseluruhan responden setuju terhadap poin-poin yang ditanyakan dalam kuesioner yaitu dengan nilai rata-rata 3,39 .

\section{PENUTUP}

Terdapat beberapa hal yang dapat disimpulkan setelah dilaksanakannya penelitian ini dan digunakannya aplikasi yang dibuat untuk kegiatan PMB di STMIK Atma Luhur. Berdasarkan Skala Likert pada kuesioner yang disebarkan terhadap 475 responden, responden setuju bahwa proses pendaftaran camaba STMIK Atma Luhur menjadi lebih mudah dan efisien dengan nilai rata-rata sebesar 3,33. Hal ini dikarenakan camaba dapat mendafar di STMIK Atma Luhur dari mana saja dan kapan saja dengan aplikasi yang dibuat. Selain itu, responden setuju bahwa aplikasi juga memudahkan dan mempercepat pekerjaan panitia PMB dengan nilai rata-rata 3,48 . Hal ini disebabkan pendaftaran camaba dengan aplikasi yang dibuat datanya terintegrasi dengan database Oracle kampus, sehingga panitia PMB tidak perlu menginput ulang data camaba dan proses pendaftaran menjadi lebih cepat serta mudah. Terakhir, informasi terkait PMB seperti pengumuman, fasilitas, dan biaya perkuliahan di STMIK Atma Luhur dapat diakses dengan mudah, menarik, dan jelas dengan menggunakan aplikasi yang dibuat memiliki nilai skala Likert sebesar 3,25. Fitur push notification pada aplikasi memungkinkan panitia PMB mengetahui dan memproses segera mungkin jika ada pendaftaran camaba baru sehingga tidak perlu lagi mengecek ada tidaknya pendaftaran camaba baru secara berkala. Selain itu, camaba bisa langsung mendapatkan pemberitahuan apabila pendaftarannya ditanggapi panitia PMB atau terdapat perubahan jadwal pengarahan.

\section{REFERENSI}

[1] E. N. Jannah, D. K. Bayturrohman, and E. Kurniawan, "Pengembangan Aplikasi Penerimaan Mahasiswa Baru Berbasis Android Dilengkapi dengan Fitur Push Notification," J. Nas. Tek. Elektro dan Teknol. Inf., vol. 6, no. 4, pp. 410-415, 2017. 
[2] Y. S. Japriadi and L. Tommy, "Prototipe Aplikasi Ujian Coding PHP Berbasis Web Intranet di STMIK Atma Luhur," J. Ilmu Pengetah. dan Teknol. Komput., vol. 5, no. 1, pp. 73-80, 2019.

[3] L. Tommy, C. Kirana, and V. Lindawati, "Recommender System dengan Kombinasi Apriori dan Content-Based Filtering pada Aplikasi Pemesanan Produk," Journal Teknoinfo, vol. 13, no. 2, pp. 84-95, 2019.

[4] A. Fatkhudin and D. N. Alifiani, "Sistem Informasi Pendaftaran Pasien pada Klinik Dr. Veri Kajen Kabupaten Pekalongan Berbasis Android," J. Ilm. Edutic, vol. 4, no. 1, pp. 51-58, 2017.

[5] Y. Lestari Diyah, P. Rahardjo, and Mardiyono, "Aplikasi Android untuk Pendaftaran Poliklinik Anak, Gigi, dan Mata di RSUD Dokter R. Soetijono Blora," J. Tek. Elektro Terap., vol. 5, no. 1, pp. 7-12, 2016.

[6] A. Anisah and S. Sayuti, "Perancangan Sistem Informasi Registrasi Online Untuk Penerimaan Siswa Baru Berbasis Web Pada SMK Negeri 1 Kelapa Bangka Barat," J. Sisfokom (Sistem Inf. dan Komputer), vol. 7, no. 2, p. $174,2018$.

[7] R. Adisaputra, E. Hernawati, and G. P. Kusuma, "Aplikasi Pendaftaran dan Penerimaan Siswa Baru Berbasis Web (Studi Kasus: SMPN 2 Cianjur)," in e-Proceeding of Applied Science, 2018, vol. 4, no. 1, pp. 131-139.

[8] F. Putrawansyah, "Aplikasi Computer Assisted Test (CAT) pada Penerimaan Mahasiswa Baru Sekolah Tinggi Teknologi Pagar Alam (STTP)," J. RESTI (Rekayasa Sist. dan Teknol. Informasi), vol. 1, no. 1, pp. 1-8, 2017.

[9] R. Witanto and H. H. Solihin, "Perancangan Sistem Informasi Penerimaan Siswa Baru Berbasis Web (Studi Kasus: SMP Plus Babussalam Bandung)," J. Infotronik, vol. 1, no. 1, pp. 54-63, 2016.

[10] M. A. Rosid and R. B. Jakaria, "Implementasi Framework Twitter Bootstrap dalam Perancangan Aplikasi Penerimaan Mahasiswa Baru Berbasis Web," J. Kinet., vol. 1, no. 3, pp. 129-134, 2016.

[11] E. N. Candra, J. Siregar, and S. Rukiastiandari, "Aplikasi Pendaftaran Pasien Rawat Jalan Rumah Sakit Meilia Cibubur Berbasis Web," J. Gaung Inform., vol. 12, no. 1, pp. 35-45, 2019.

[12] F. Mubarok, Harliana, and I. Hadijah, "Perbandingan Antara Metode RUP dan Prototype dalam Aplikasi Penerimaan Siswa Baru Berbasis Web," J. Creat. Inf. Technol., vol. 2, no. 2, pp. 114-127, 2015.

[13] R. E. Putri, "Perancangan Sistem Informasi Registrasi Ulang Penerimaan Siswa Baru Berbasis Web,” J. Techsi, vol. 9, no. 2, pp. 139-147, 2017.

[14] Irfan and D. Soyusiawaty, "Aplikasi Penerimaan Siswa Baru Reguler(PSB) Online Berbasis Web dan Mobile yang Terintegrasi dengan SMS Gateway Studi Kasus di Sma Negeri 1 Pengasih," J. Sarj. Tek. Inform., vol. 3, no. 1, pp. 161-168, 2015.

[15] M. R. Meta, I. E. Putra, and A. Urfa, "Aplikasi Penerimaan Mahasiswa Baru Online dengan SMS Gateway di STMIK Indonesia Padang," $J$. RESTI (Rekayasa Sist. dan Teknol. Informasi), vol. 2, no. 3, pp. 716-721, 2018.

[16] A. A. Ivanka, Suryatiningsih, and W. Muhamad, "Aplikasi Penerimaan Siswa Baru Berbasis Web Menggunakan SMS Gateway," in $e$ Proceeding of Applied Science, 2017, vol. 3, no. 2, pp. 813-823.

[17] N. M. D. Wulansari, Didiklah Anak Sesuai Zamannya: Mengoptimalkan Potensi Anak di Era Digital, 1st ed. Jakarta: V Media, 2017.

[18] A. Prihantini, Master Bahasa Indonesia: Panduan Tata Bahasa Indonesia Terlengkap, 1st ed. Yogyakarta: B First, 2015.

[19] S. Nurhalimah and Dkk, Media Sosial Dan Masyarakat Pesisir : Refleksi Pemikiran Mahasiswa Bidikmisi. Yogyakarta: Deepublish, 2019.

[20] Y. Yudhanto and A. Wijayanto, Mudah Membuat dan Berbisnis Aplikasi Android dengan Android Studio, 1st ed. Jakarta: Elex Media Komputindo, 2017.

[21] C. Bilgin, Hands-On Mobile Development with .NET Core: Build CrossPlatform Mobile Applications with Xamarin, Visual Studio 2019, and .NET Core 3, 1st ed. Birmingham: Packt Publishing, 2019.

[22] A. Bastian and A. Y. Budiman, "Implementasi Piranti Jaringan Repeater Eco Village Menggunakan Model Prototype dan Konsep Green Computing," J. Ilm. Teknol. Inf. Terap., vol. 3, no. 3, pp. 233-240, 2017. 